Archived version from NCDOCKS Institutional Repository http://libres.uncg.edu/ir/asu/

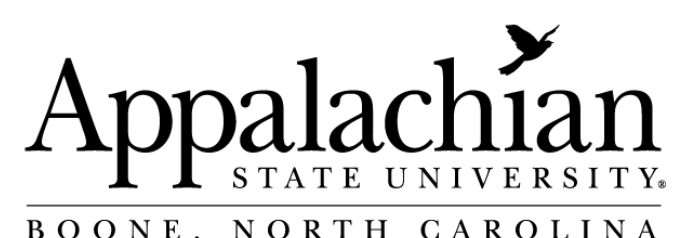

B O O N E, NORT H C A R O L I N A

\title{
CEO International Assignment Experience and Corporate Social Performance
}

\author{
Authors: \\ Daniel J. Slater and Heather R. Dixon-Fowler
}

\begin{abstract}
Research suggests that international assignment experience enhances awareness of societal stakeholders, influences personal values, and provides rare and valuable resources. Based on these arguments, we hypothesize that CEO international assignment experience will lead to increased corporate social performance (CSP) and will be moderated by the CEO's functional background. Using a sample of 393 CEOs of S\&P 500 companies and three independent data sources, we find that CEO international assignment experience is posi- tively related to CSP and is significantly moderated by the CEO's functional background. Specifically, CEOs with international assignment experience and an output func- tional background (e.g., marketing and sales) are positively associated with greater CSP.
\end{abstract}

Daniel J. Slater and Heather R. Dixon-Fowler (2009) "CEO International Assignment Experience and Corporate Social Performance" Journal of Business Ethics Vol. 89, No. 3 pp. 473-489 Version of record available @ (DOI 10.1007/s10551-008-0011-y) 


\title{
CEO International Assignment Experience and Corporate Social Performance
}

\author{
By: Daniel ]. Slater \\ Heather R. Dixon-Fowler
}

\begin{abstract}
Research suggests that international assignment experience enhances awareness of societal stakeholders, influences personal values, and provides rare and valuable resources. Based on these arguments, we hypothesize that CEO international assignment experience will lead to increased corporate social performance (CSP) and will be moderated by the CEO's functional background. Using a sample of 393 CEOs of S\&P 500 companies and three independent data sources, we find that CEO international assignment experience is positively related to CSP and is significantly moderated by the CEO's functional background. Specifically, CEOs with international assignment experience and an output functional background (e.g., marketing and sales) are positively associated with greater CSP.
\end{abstract}

KEY WORDS: corporate social performance, corporate social responsibility, international experience, upper echelons, KLD

Corporate social performance (CSP) represents a firm's "configuration of principles of social responsibility, processes of social responsiveness, and policies, programs, and observable outcomes as they relate to the firm's societal relationships" (Wood, 1991,

p. 693). Essentially, CSP requires firms to meet the performance expectations of societal stakeholders (McGuire et al., 2003). Examples of societal stakeholders affected by firms' strategic decisions and actions include local communities, minorities, employees, customers, and the natural environment (Berman et al., 1999; Coombs and Gilley, 2005). As a result of increasing stakeholder pressure, general societal trends, and institutional forces (e.g., Kyoto Protocol, "best of" rankings) the demands on firms to manage both profits and social responsibility have increased (Waddock and Graves, 1997).
However, societal stakeholders are not the sole beneficiaries of CSP - firms themselves may reap benefits from engaging in CSP initiatives. Firms able to meet or exceed societal expectations may develop strong positive reputations (Turban and Greening, 1996), enhance firm legitimacy (Handelman and Arnold, 1999), strengthen firm image (Brown and Dacin, 1997), reduce risk (Husted, 2005), develop valuable organizational capabilities (Sharma and Vredenburg, 1998), and are more likely to be viewed as ethical (Valentine and Fleischman, 2008).

With potentially beneficial outcomes for both society and firms themselves, it is becoming increasingly important to understand the antecedents

of CSP (Waldman et al., 2006). Previous research has noted the importance of investigation on relevant managerial variables (Thomas and Simerly, 1994;

Wood, 1991). Specifically, the role of the CEO has been recognized due to its significant influence on CSP initiatives (Agle et al., 1999). As the leader of the firm, the CEO plays a primary role in strategic decision making and resource allocation

(Hosmer, 1982; Mintzberg, 1978). Therefore, we would expect the CEO to play a significant role in decisions involving CSP strategies and the amount of resources devoted to such pursuits. Previous research has supported the relationship between the

CEO and CSP (Hemingway and Madagan, 2004; Simerly, 2000; Thomas and Simerly, 1994; Wood, 1991). Much of this previous research is grounded in the upper echelons perspective. Upper echelons research suggests that executives' experiences, values, and personalities will affect their field of vision, selective perception, interpretation, strategic choices, and ultimately firm performance

(Finkelstein and Hambrick, 1996; Hambrick and Mason, 1984; Jackson, 1992). As a result, 
organizations become, at least in part, a reflection of their CEO (Hambrick and Mason, 1984).

Upper echelons researchers have extended their empirical examination beyond the relationships between conventional demographic variables (e.g., age, tenure, education) and firm financial performance to a broader set of executive characteristics and organizational outcomes (Carpenter et al., 2004; Hambrick, 2007). One of these "broader" executive characteristics receiving attention by organizational researchers is international assignment experience - that is the experience of living and working in a foreign country (e.g., Carpenter et al., 2003; Gregersen et al., 1998). CEO international assignment experience has been related to higher salaries (Carpenter et al., 2001), greater firm internationalization (Athanassiou and Nigh, 2000), and increased firm financial performance (Daily et al., 2000). In addition, research findings suggest that international experience influences personal values (Suutari and Makela, 2007) and provides the CEO with rare and valuable resources (Carpenter et al., 2001). These findings prompted the primary question addressed by the current research - is there a relationship between CEO international assignment experience and CSP?

Our secondary question addresses a potential moderator to this relationship. A consistent finding in upper echelons research is that functional background has a significant influence on how executives think and act. Specifically, functional background has been shown to directly influence goal orientations, time frames, the way problems are defined, information processing, and strategic choices (Lawrence and Lorsch, 1967; Walsh, 1988). As such, we might expect international assignment experience to have differential influences on the CEO based on their functional background. Thus, we also address a secondary question-does functional background moderate the relationship between CEO international assignment experience and CSP?

By addressing these questions, our study will contribute to existing knowledge in three areas. First, we will explore an important and previously unidentified antecedent of CSP. Second, we will contribute to our understanding of CEO international assignment experience by examining a new firm and societal level outcome. Finally, we will seek to further extend upper echelons research by connecting yet another executive characteristic (international assignment experience) to an important firm outcome (CSP) and exploring specific conditions under which this relationship may be most effective (depends on CEO functional background).

The remainder of the paper will unfold as follows. First, the following section discusses CSP in greater detail. Second, hypotheses will be developed on CEO international experience and CSP as well as the main and moderating effects of CEO functional background. Third, research methodology, analysis, and results are presented. Finally, the paper concludes with a discussion of the results, implications, limitations and future research, and concluding thoughts.

\section{Corporate social performance}

As previously stated, CSP requires firms to meet the performance expectations of societal stakeholders (McGuire et al., 2003). In order to meet the expectations of these stakeholders, firms may invest in social objectives in which returns are uncertain. But by focusing on long-term objectives and meeting or exceeding societal expectations, these firms expect to be profitable in the long term (Kane, 2002). Adding to this challenge, the demands of multiple stakeholders may conflict. For example, a firm may allocate scarce financial resources to local charities satisfying community stakeholders while neglecting employee expectations for use of those funds toward enhanced retirement benefits. Thus, meeting the demands of multiple stakeholders requires complex strategies in order to achieve a constant balance.

Many previous investigations have conceptualized CSP along a single continuum from weak to strong (Agle et al., 1999; Hillman and Keim, 2001; Turban and Greening, 1996; Waddock and Graves, 1997). In such approaches, a firm's influence on each stakeholder group is either weak or strong and these weaknesses and strengths are viewed in aggregate to represent the CSP construct. As such, firms may exhibit weak or strong CSP depending on whether weaknesses outweigh strengths or vice versa.

More recent studies have proposed that CSP strengths and weaknesses may not necessarily represent opposite ends of a single continuum, but rather 
they are less orthogonal and should be considered separately (Mahoney and Thorn, 2006; McGuire et al., 2003; Strike et al., 2006). McGuire et al. (2003) suggests that CSP strengths represent more proactive positions and initiatives toward stakeholders (e.g., development of innovative products with environmental benefits), whereas CSP weaknesses are indicative of socially risky strategies or avoidance approaches (e.g., poor health and safety standards for employees). Conceptualized along separate continuums, firms may exhibit CSP strength and CSP weakness simultaneously (Strike et al., 2006). In addition, single continuum approaches do not recognize the potential for socially irresponsible actions for which there is no socially responsible counterpart. For example, Strike et al. (2006) note that violence against employees would be considered by most to be socially irresponsible. However, the absence of violence is not necessarily responsible, but rather a legal and societal norm.

Although CSP strengths and weaknesses may not be orthogonal, a more holistic consideration requires an examination of CSP strengths countered by CSP weaknesses. In other words, while single continuum conceptualizations may ignore simultaneous expression, allowing weaknesses to offset strengths appears necessary in order to obtain a single snapshot picture of a firm's total or net CSP. Therefore, following Mahoney and Thorn (2006), we will conceptualize (and will subsequently operationalize) CSP using both approaches - CSP strengths and weaknesses separately, and total CSP. Thus, we are able to explore the potentially differential outcomes for strengths and weaknesses while also examining the larger picture of total CSP.

\section{CEO international assignment experience and CSP}

The growing body of research on executive international experience and organizational-level outcomes has largely examined the positive relationship between the international experience of top managers and the degree of firm internationalization (e.g., Athanassiou and Nigh, 2000; Carpenter et al., 2003; Carpenter and Fredrickson, 2001). Additional studies have expanded the focus to suggest a relationship between CEO international experience, firm internationalization, and higher firm financial performance (Carpenter et al., 2001; Daily et al., 2000; Roth, 1995; Sambharya, 1996). Interestingly, outside CEO successors with international experience are significantly and positively related with all three traditional firm performance measures (ROI, ROA, and market-to-book ratio; Daily et al., 2000). Similarly, international assignment experience was found to have a positive relationship with both accounting and market measures of firm performance for multinational corporations (Carpenter et al., 2001). One of the mechanisms suggested for this relationship is the additional cognitive and social resources gained by the $\mathrm{CEO}$ through international assignment experience (Carpenter et al., 2001).

\section{Rare and valuable resources}

CEOs with international assignment experience represent a rare and valuable resource (Carpenter et al., 2001). In fact, many firms recognize this valuable resource and are willing to pay higher salaries to CEOs with international assignment experience, indicating some level of enhanced human capital (Carpenter et al., 2001). International assignments often involve a much greater breadth of responsibilities than typical of domestic activities (Suutari and Makela, 2007). Through exposure to new and foreign value systems, languages, and institutional environments executives must develop new solutions as issues arise instead of falling back on proven strategies in more familiar territory (Ricks et al., 1990). International assignment also affords the executive high levels of autonomy which instills confidence in personal decisions as successful solutions are found (Suutari and Makela, 2007). Combining the breadth of responsibilities, need for innovative solutions, and autonomy executives with international assignment experience become much more adept at processing complex and dynamic information (Carpenter et al., 2001).

This increased ability to process complex information not only enhances international competencies, such as predicting the needs of foreign customers, it also enhances general managerial competencies such as leadership and change management (Suutari and Makela, 2007). We suggest that this enhanced ability to process complex and dynamic information may also 
translate to CSP. This enhanced ability could prove invaluable when attempting to meet the conflicting demands of multiple stakeholders. Pursuit of satisfying the expectations of multiple societal stakeholders while also remaining mindful of firm financial stability - will require innovative solutions in constantly changing competitive environments. These innovative solutions will likely draw on the ability of the firm's chief decision maker to process this complex information.

In addition to enhanced ability to process complex information, international assignment experience also increases the CEOs global network (Edstrom and Galbraith, 1977; Suutari and Makela, 2007). As new and difficult societal demands arise, the CEO has a novel and valuable network on which to draw for advice or assistance in development of a social initiative (e.g., recruitment of a more diverse workforce). Therefore, with enhanced ability to process complex information and a unique global network, international assignment experience provides the $\mathrm{CEO}$ with rare and valuable resources which may be used to influence their firm's CSP.

\section{Awareness of societal stakeholders}

The experience of living and working in a foreign country may also influence the cognitive orientation of executives (Hermann and Datta, 2005; Ricks et al., 1990). Executives often report that their international assignment experience has lasting impacts on their worldviews and how they manage their firms (Carpenter et al., 2000; Gregersen et al., 1998; Kohonen, 2004). In fact, executives with international assignment experience report that it is the most important experience of their careers (Gregersen et al., 1998). In-depth interviews of managers following international assignments indicate a transformational impact on identity (Kohonen, 2004). Research also suggests that when top man- agers have international experience, their perceptions and personality take on a more international orientation resulting in a global mindset as a result of exposure to different value systems and institutional environments (Gunz and Jalland, 1996; Ricks et al., 1990; Sambharya, 1996). Thus, CEOs with international assignment experience may be aware of a broader set of stakeholders.
This notion is also supported by research on study abroad experiences of students. ${ }^{1}$ International experience has been shown to influence students' inter- national perspectives (Kauffinann et al., 1992; Zorn, 1996), awareness, and appreciation (Carlson and Widaman, 1988; Dwyer, 2004; Wallace, 1999). This influence has also been shown to have a longterm effect on shaping and influencing evaluation of world issues (Dwyer, 2004; Zorn, 1996). Specifically, individuals who studied abroad experienced a greater awareness of global interconnectedness (Chieffo and Griffiths, 2004). Thus, international experience may enhance the CEOs ability to meet societal expectations by increasing their awareness of a broader set of stakeholder demands.

\section{Personal values}

Personal values represent individual beliefs about desirable behaviors (Schwartz and Bilski, 1987). These values often have a strong motivational component and guide individual actions, behaviors, and attitudes (Rokeach, 1973). Exposure to a different culture often leads executives to rethink their own behavior and value structures (Suutari and Makela, 2007). This finding is also supported by research on student international experience. Studying abroad may lead to an increased interest in world political and social issues, increased interest in world economic conditions, greater open-mindedness and tolerance of differences, increased empathy (Black and Duhon, 2006; Thomlison, 1991), and increased sense of responsibility and respect for others (Chieffo and Griffiths, 2004). Many of these personal out- comes may influence a CEOs motivation toward pursuing CSP. For example, a CEO with a greater sense of responsibility toward others may be more likely to encourage charitable contributions toward local housing and education initiatives. Likewise, a CEO who empathizes with frustrated customers may be more likely to pursue quality improvements in their product.

There are also reasons to suspect that the motivating influence of international experience remains in effect long after the experience itself $\mathrm{A}$ large-scale longitudinal survey of alumni who participated in study abroad programs between 1950 and 1999 reported that $98 \%$ of respondents indicated that their 
international experience continued to influence how they viewed the world (Dwyer, 2004). Interestingly, there were no significant differences in participants' responses over each of the four decades suggesting that international experience has an important longterm effect (Dwyer, 2004). Thus, the effects of international assignment experience may not diminish over time but rather may provide lasting motivation for CEOs and the firm's they lead.

These findings support the assertion by Hemingway and Madagan (2004) that the personal values of individual managers is one of the drivers of CSP. Through international experience, values may be changed or strengthened (e.g., enhanced empathy and respect for others) in such a way to motivate the CEO toward pursuing increased CSP - leading the firm to become, at least in part, a reflection of its CEO (Hambrick and Mason, 1984).

Up to this point, we have argued that international assignment experience provides the CEO with rare and valuable resources (e.g., enhanced ability to process complex information and global networks), increased awareness of societal expectations (e.g., global stakeholders and interconnectedness), and changed or strengthened personal values (e.g., open- mindedness). With potentially greater societal awareness, motivation to act (through personal values), and unique resources, combined with the discretion and power afforded by their position, we suggest that CEOs with international assignment experience are willing and able to enhance their firms' CSP. Thus, we hypothesize:

$H$ ta: CEO international assignment experience will be positively associated with corporate social performance strengths.

$H t b$ : CEO international assignment experience will be negatively associated with corporate social performance weaknesses.

$H$ tc: CEO international assignment experience will be positively associated with total corporate social performance.

\section{CEO functional background}

Functional background is a common executive characteristic studied in upper echelons research due to its influence on strategic choice (Hambrick and Mason, 1984) and the association with a variety of firm outcomes (e.g., Gupta and Govindarajan, 1984; Hambrick and Mason, 1984; Song 1982; Thomas et al., 1991). An executive's functional background has been shown to directly influence goal orientations, time frames, the way problems are defined, information processing, and strategic choices (Lawrence and Lorsch, 1967; Walsh, 1988).

Hambrick and Mason (1984) first identified the more internally oriented functional backgrounds such as production, process $\mathrm{R} \& \mathrm{D}$, accounting, and finance as 'throughput' backgrounds, and the more externally oriented backgrounds such as marketing, sales, merchandizing, product R\&D, and entrepreneurship as 'output' backgrounds. Researchers have previously argued that managers with output- oriented backgrounds will be better able to recognize the demands of their stakeholders (Simerly, 2000; Thomas and Simerly, 1994). Conversely, managers with more internally oriented backgrounds will be more task-oriented and not as sensitive to the needs of stakeholders (Simerly, 2000). The relationship between functional background and CSP has been examined in prior studies which provide support for the argument that output-oriented functional background does lead to higher levels of CSP (Simerly, 2003; Thomas and Simerly, 1994). Consistent with previous research, we hypothesize:

H2a: CEO output functional background will be positively associated with corporate social performance strengths.

$H 2 b$ : CEO output functional background will be negatively associated with corporate social performance weaknesses.

H2c: CEO output functional background will be positively associated with total corporate social performance.

Beyond the main effect of functional background, the greater concern for the present study is the potential moderating effect of functional background on the relationship between CEO international assignment experience and CSP. Specifically, we suggest that the positive benefits of international experience will have the greatest impact on CEOs with output functional backgrounds, thus leading to even higher levels of CSP. 
Functional background has been argued to shape executives' perceptions and cognitions (e.g., Beyer et al., 1997; Hambrick and Mason, 1984). Therefore, the enhanced awareness, personal values, and resources resulting from international assignment experience are filtered through different perceptions and cognitions based on the functional background of the CEO. Because they were already more attuned to stakeholder demands, CEOs with output backgrounds are more likely to utilize their increased empathy, greater tolerance, and enhanced ability to process complex information toward pursuit of CSP initiatives. Conversely, CEOs with throughput functional backgrounds may be less likely to fully capitalize on the benefits of international assignment experience because their functional background does not generally consider the demands of external stakeholders. Thus, we hypothesize:

H3a: CEO functional background will moderate the relationship between CEO international experience and CSP strengths, such that the positive relationship between CEO international experience and CSP strengths will be stronger for CEOs with output functional backgrounds.

$H 3 b$ : CEO functional background will moderate the relationship between CEO international experience and CSP weaknesses, such that the negative relationship between CEO international experience and CSP weaknesses will be more negative for CEOs with output functional backgrounds.

H3c: CEO functional background will moderate the relationship between CEO international experience and total CSP, such that the positive relationship between CEO international experience and total CSP will be stronger for CEOs with output functional backgrounds.

\section{Method}

\section{Data sources}

Three independent data sources were compiled for testing hypotheses in this study. First, CEO biographical information (age, tenure, functional background, and international work experience) was obtained from Spencer Stuart - a global executive search firm.2 Spencer Stuart's data were compiled from the following sources: Marquis Who's Who in America; The Corporate Yellow Book; 50,000 Leading U.S. Corporations-Business Trends; Standard and Poor's Register of Corporations, Directors and Executives; QuestNT (Spencer Stuart's proprietary database); corporate websites and press releases; company proxies; OneSource.com; Hoovers.com; and information requests directly to the firm when necessary. Second, all firm level performance data (firm size, performance, research and development (R\&D) intensity, and internationalization) were retrieved from COMPUSTAT. Third, consistent with a large and growing body of CSP research (Agle et al., 1999; Berman et al., 1999; Coombs and Gilley, 2005; Graves and Waddock, 1994; Hillman and Keim, 2001; Johnson and Greening, 1999; McWilliams and Siegel, 2000; Sharfman, 1996; Turban and Greening, 1996; Waddock and Graves, 1997; Waldman et al., 2006), we gathered corporate social performance data from KLD Research and Analytics Inc., an independent investment research firm specializing in firm ratings of environment, social, and governance performance for use in investment decisions. KLD provides multiple CSP indicators across multiple dimensions of CSP to be discussed further below. The data from these three independent sources were merged and analyzed for tests of this study's hypotheses.

\section{Sample}

Our initial sample comprised U.S. CEOs from the S\&P 500 in 2004 - totaling 502 CEOs (two companies were lead by dual CEOs). The CSP measures for this study are based on annual data from 2004 so we excluded cases where the CEO was not in office as of January 1st, 2004 (76 CEOs). Therefore, all CEOs evaluated had tenure as CEO for at least one year and were thus in a position to influence the CSP of their firm in the target year. Thirty-three cases were also eliminated from the study due to missing data leaving a final sample size of 393. The final sample mean age $=56(\mathrm{SD}=6.8)$, mean company tenure $=18.7(\mathrm{SD}=11.5)$, and mean tenure as $\mathrm{CEO}=7.9$ years $(\mathrm{SD}=6.8) .97 .5 \%$ held at least a bachelor's degree and $65 \%$ held at least one 
graduate degree. In addition, the CEOs in our sample represented firms from 53 different industries based on their two digit level SIC code.

\section{Measures}

International assignment experience

Following previous research (Herman, 2002), CEO international assignment experience was operationalized as a categorical variable indicating whether or not the CEO has spent time on international assignment (Hermann and Datta, 2005; Sambharya, 1996). Categorization was based on clear indications of international assignment experience in published CEO biographies, annual reports, company websites, and other sources.

\section{Outputfunctional background}

As introduced by Hambrick and Mason (1984), executive functional backgrounds have often been categorized as output (e.g., marketing, sales, product research, and development) and throughput (e.g., production, process engineering, and finance). Prior research has often used this classification to measure executives' functional background (Herman, 2002; Hermann and Data, 2005; Thomas and Simerly, 1994). Similarly, we categorized CEO functional background as either output (1) or throughput $(0){ }^{3}$

\section{Corporate social peiformance}

We measured corporate social performance using the dimensions of community, diversity, employee relations, environmental impact, and product safety and quality 4 because these categories best reflect the stakeholder orientation of CSP (Agle et al., 1999). In addition, these categories are most common in extant CSP research (Berman et al., 1999; Coombs and Gilley, 2005), thus providing a bases for comparison.

Consistent with Mahoney and Thorn (2006), we operationalized CSP in three forms, strengths, weaknesses, and total CSP. Each firm is rated between 0 and 2 on strength and on weakness in each of the five dimensions referenced above..$^{5}$ A score of 2 indicates a major strength or weakness, a score of 1 indicates a notable strength or weakness and a score of 0 indicates neutral strength or weakness. Strength and weakness scores are then separately summed across all five dimensions to provide indices for strengths and weaknesses, respectively. This calculation of CSP strengths and weaknesses is consistent with previous operationalizations of CSP (Mahoney and Thorn, 2006;6 McGuire et al., 2003).

The total CSP measure was also created following prior use of the KLD index (Agle et al., 1999; Hillman and Keim, 2001; Turban and Greening, 1996; Waddock and Graves, 1997). The total CSP measure represents net CSP by subtracting the weakness score from the strength score. Thus, scores within each stakeholder group can range from -2 to 2. A score of -2 represents a major weakness, $-\mathbf{1}$ represents a notable weakness, 0 represents neutrality within the category, 1 represents a notable strength, and 2 represents a major strength. The net or total CSP scores for each stakeholder group are then summed to create the total CSP measure.

\section{Control measures}

\section{Industry}

Industry has been shown to have significant effects on ratings of corporate social performance (Waddock and Graves, 1997). We controlled for industry by adjusting all three forms of the dependent variable (strengths, weaknesses and total CSP) based on industry averages at the 2 digit level SIC code. Consistent with Waldman et al. (2006) the industry average was subtracted from the firm score to represent an industry adjusted value. ${ }^{7}$

\section{Firm size}

Firm size has been found to be related to CSP (Graves and Waddock, 1994). Therefore, we controlled for firm size using the natural $\log$ of sales for each firm.

\section{Firm peiformance}

Prior firm performance has been found to predict CSP (Waddock and Graves, 1997).We controlled for prior firm performance using a 3-year lagged (2001-2003) average of return on assets for each firm.

\section{Firm R\&D intensity}

Prior research has also shown that firm investment in R\&D is related to CSP (McWilliams and Siegel, 2000; Waldman et al., 2006). Therefore, we controlled for R\&D intensity consistent with prior research using the ratio of $R \& D$ expenses to sales. 


\section{Finn internationalization}

Firm internationalization reflects the degree to which a company engages in international business activity such as foreign sales and reliance on foreign production. Carpenter et al. (2001) found firm internationalization to be related to CEO international experience which presents a potential confound for the present study. We controlled for firm internationalization using a variation of the Carpenter et al. (2001) measure -the sum of two ratios, foreign sales to total sales and foreign assets to total assets.

\section{Age and CEO tenure}

Due to their potential influence on firm outcomes (Hambrick and Mason, 1984), CEO age and tenure (as CEO) were used as control variables in all analyses.

\section{Results}

Descriptive statistics and correlations are reported in Table $1 .{ }^{8}$ Hypotheses were tested using hierarchical regression analysis. Each of the three CSP indices was regressed on three hierarchical models. Model 1 in Tables II, III, and IV contains coefficients and model results for all control variables. Model 2 adds CEO international assignment experience and output functional background to assess their incremental effects on CSP, thus testing hypotheses la, lb, le, 2a, $2 \mathrm{~b}$, and 2c. Model 3 adds the interaction between CEO international assignment experience and CEO output functional background as a test of hypotheses $3 \mathrm{a}$, $3 \mathrm{~b}$, and $3 \mathrm{c} .9$

\section{Corporate social peifonnance strengths}

The results of four hierarchical regression analysis using the CSP strengths measure are presented in Table II. Among the control variables included in model 1, we

find that firm size $(p<0.01)$, firm $R \& D$ intensity $(p<0.01)$, and CEO age $(p<0.01)$ are significant positive predictors of CSP strength. In total, the control variables account for $26.6 \%$ of the variance in the strengths measure $(F=24.698 ; p<0.01)$. Model 2 shows that CEO international assignment experience is a significant positive predictor of CSP strengths $(p<0.01)$, supporting hypothesis la. CEO output functional background was not a significant predictor of CSP strengths $(p>0.05)$, thus we find no support for hypothesis $2 \mathrm{a}$. Model 3 indicates that the interaction between CEO international assignment experience and CEO output functional background is a significant positive predictor of CSP strengths $(p<0.01)$ supporting hypothesis $3 \mathrm{a}$.

\section{Corporate social peifonnance weaknesses}

The results of our hierarchical regression analysis using the CSP weaknesses measure are presented in Table III. Among the control variables included in model 1 , we find that firm size $(p<0.01)$ is a significant positive predictor, while firm performance $(p<0.01)$ and CEO tenure $(p<0.01)$ are significant negative predictors of CSP weaknesses. In total, the

control variables account for $30 \%$ of the variance in the weaknesses measure $(\mathrm{F}=29.008 ; p<0.01)$. Models 2 and 3 show that neither CEO international experience $(p>0.05)$, CEO output functional background $(p>0.05)$, nor the interaction between CEO international assignment experience and CEO output functional background $(p>0.05)$ are significant predictors of CSP weaknesses. Thus, hypothesis

$1 b, 2 b$, and $3 b$ are not supported.

\section{Total corporate social peifonnance}

The results of our hierarchical regression analysis using the total CSP measure are presented in Table IV. ${ }^{10}$ Among the control variables included in model 1 , we find that firm performance $(p<0.01)$ and firm R\&D intensity $(p<0.01)$ are significant positive predictors of total CSP. The control variables account for $6.4 \%$ of the variance in the total CSP measure $(F=5.496$; $p<0.01)$. Model 2 shows that CEO international assignment experience is a significant positive predictor of total CSP $(p<0.05)$, supporting hypothesis 1c. CEO output functional background is a significant positive predictor of total CSP $(p<0.05)$, supporting hypothesis $2 c$. Model 3 indicates that the interaction

between CEO international assignment experience and CEO output functional background is also a significant positive predictor of total CSP $(p<$ 0.05 ) supporting hypothesis $3 c$.

\section{Interaction analysis}

A further examination of the significant interaction between CEO international assignment experience 
TABLE I

Descriptive statistics and correlations

\begin{tabular}{|c|c|c|c|c|c|c|c|c|c|c|c|c|}
\hline Variable & Mean & SD & 1 & 2 & 3 & 4 & 5 & 6 & 7 & 8 & 9 & 10 \\
\hline 1. Firm size & 8.87 & 1.18 & & & & & & & & & & \\
\hline 2. Firm performance & 3.14 & 15.73 & 0.08 & & & & & & & & & \\
\hline 3. Firm R\&D intensity & 3.47 & 6.54 & $-0.33 \star \star$ & $-0.12^{\star}$ & & & & & & & & \\
\hline $\begin{array}{l}\text { 4. Firm } \\
\text { internationalization }\end{array}$ & 26.76 & 30.25 & $-0.11^{\star}$ & 0.00 & $0.37^{\star \star}$ & & & & & & & \\
\hline 5. CEO age & 56.03 & 6.82 & 0.09 & 0.05 & $-0.15^{\star \star}$ & -0.06 & & & & & & \\
\hline 6. CEO tenure & 7.97 & 6.82 & -0.06 & 0.08 & 0.02 & 0.02 & $0.46^{\star \star}$ & & & & & \\
\hline $\begin{array}{l}\text { 7. CEO output } \\
\text { background }^{2}\end{array}$ & 0.34 & 0.47 & -0.04 & 0.00 & $0.22 \star \star$ & $0.14^{\star \star}$ & $-0.20^{\star \star}$ & $-0.13^{\star \star}$ & & & & \\
\hline $\begin{array}{l}\text { 8. CEO international } \\
\text { experience }^{*}\end{array}$ & 0.34 & 0.47 & $0.10^{\star}$ & 0.02 & $0.16^{\star \star}$ & $0.33^{\star \star}$ & -0.03 & $-0.16^{\star \star}$ & $0.12^{\star}$ & & & \\
\hline 9. CSP strengths ${ }^{b}$ & 1.36 & 1.73 & $0.42 \star \star$ & 0.03 & $0.14^{\star \star}$ & 0.08 & $0.11^{\star}$ & -0.04 & $0.10^{\star}$ & $0.24 \star \star$ & & \\
\hline 10. CSP weaknesses & 0.70 & 1.47 & $0.50 \star \star$ & $-0.14^{\star \star}$ & -0.09 & -0.06 & 0.02 & $-0.18 \star \star$ & -0.06 & $0.10^{\star}$ & $0.27 \star \star$ & \\
\hline 11. CSP total ${ }^{b}$ & 0.67 & 1.94 & -0.01 & $0.13 \star \star$ & $0.19 \star \star$ & $0.12^{\star}$ & 0.08 & $0.10^{\star}$ & $0.14 \star$ & $0.14 \star \star$ & $0.68^{\star \star}$ & $-0.52^{\star \star}$ \\
\hline
\end{tabular}


Daniel ]. Slater and Heather R. Dixon-Fowler

TABLE II

CEO international assignment experience and CSP strengths

\begin{tabular}{lccc}
\hline Variable & Model 1 & Model 2 & Model 3 \\
\hline Firm size & $0.505(10.947)^{* * *}$ & $0.480(10.402)^{* *}$ & $0.483(10.548)^{* *}$ \\
Firm performance & $0.024(0.551)$ & $0.018(0.411)$ & $0.008(0.179)$ \\
Firm R\&D intensity & $0.321(6.464)^{* *}$ & $0.293(5.857)^{* *}$ & $0.278(5.570)^{* *}$ \\
Firm internationalization & $0.029(0.629)$ & $-0.021(-0.436)$ & $-0.006(-0.125)$ \\
CEO age & $0.147(2.956)^{* *}$ & $0.143(2.872)^{* *}$ & $0.139(2.822)^{* *}$ \\
CEO tenure & $-0.088(-1.781)$ & $-0.054(-1.082)$ & $-0.052(-1.059)$ \\
CEO international experience & & $0.143(3.050)^{* *}$ & $0.131(2.810)^{* *}$ \\
CEO output background & & $0.064(1.433)$ & $0.057(1.288)$ \\
CEO international experience $\mathrm{x}$ & & & $0.115(2.660)^{* *}$ \\
$\quad$ CEO output background & & $0.284^{* *}$ & $0.296^{* *}$ \\
Adjusted R & $0.266^{* *}$ & $5.933^{* *}$ & $7.076^{* *}$ \\
F-change & $24.698^{* *}$ & 384 & 383 \\
df & 386 & & \\
\hline
\end{tabular}

Standardized coefficients are shown with the associated $t$ statistic in parentheses.

$* * p<0.01$ (two-tailed).

TABLE III

CEO International assignment experience and CSP weaknesses

\begin{tabular}{|c|c|c|c|}
\hline Variable & Model 1 & Model 2 & Model 3 \\
\hline Firm size & $0.522(11.570)^{* *}$ & $0.522(11.448)^{* *}$ & $0.522(11.429)^{* *}$ \\
\hline Firm performance & $-0.166(-3.877)^{* *}$ & $-0.164(-3.837)^{* *}$ & $-0.164(-3.814) * *$ \\
\hline Firm R\&D intensity & $0.086(1.767)$ & $0.098(1.989)$ & $0.098(1.978)$ \\
\hline Firm internationalization & $-0.025(-0.556)$ & $-0.027(-0.573)$ & $-0.028(-0.573)$ \\
\hline CEO age & $0.067(1.379)$ & $0.054(1.101)$ & $0.054(1.100)$ \\
\hline CEO tenure & $-0.173(-3.577) * *$ & $-0.174(-3.529) * *$ & $-0.174(-3.525)^{* *}$ \\
\hline CEO international experience & & $0.027(0.575)$ & $0.027(0.576)$ \\
\hline CEO output background & & $-0.080(1.816)$ & $-0.080(1.808)$ \\
\hline CEO international experience $\mathrm{x}$ & & & $-0.002(-0.044)$ \\
\hline \multicolumn{4}{|l|}{ CEO output background } \\
\hline Adjusted $\mathrm{R}^{2}$ & $0.300 * *$ & $0.303 * *$ & $0.301 * *$ \\
\hline F-change & $29.008 * *$ & 1.763 & 0.002 \\
\hline$d f$ & 386 & 384 & 383 \\
\hline
\end{tabular}

Standardized coefficients are shown with the associated $t$ statistic in parentheses.

$* * p<0.01$ (two-tailed).

and output functional background on CSP strengths and total CSP is depicted in Figures 1 and 2. As hypothesized, the effects of CEO international experience on CSP strengths and total CSP are significantly enhanced by CEOs with output functional backgrounds compared to throughput functional backgrounds.

\section{Discussion}

Drawing from the upper echelons perspective, we have argued that international assignment experience will enhance a CEO's awareness of broader stakeholder expectations, strengthen motivation to act in society's interests (by influencing their personal 
TABLE IV

CEO International assignment experience and total CSP

\begin{tabular}{lccc}
\hline Variable & Model 1 & Model 2 & Model 3 \\
\hline Firm size & $0.053(1.023)$ & $0.031(0.591)$ & $0.034(0.647)$ \\
Firm performance & $0.148(2.987)^{* *}$ & $0.141(2.871)^{* *}$ & $0.132(2.687)^{* *}$ \\
Firm R\&D intensity & $0.221(3.938)^{* *}$ & $0.186(3.293)^{* *}$ & $0.173(3.050)^{* *}$ \\
Firm internationalization & $0.045(0.862)$ & $0.002(0.037)$ & $0.016(0.285)$ \\
CEO age & $0.080(1.426)$ & $0.086(1.531)$ & $0.083(1.480)$ \\
CEO tenure & $0.053(0.949)$ & $0.084(1.491)$ & $0.085(1.523)$ \\
CEO international experience & & $0.107(2.020)^{*}$ & $0.097(1.821)$ \\
CEO output background & & $0.118(2.335)^{*}$ & $0.112(2.219)^{*}$ \\
CEO international experience $\mathrm{x}$ & & & $0.104(2.117)^{*}$ \\
CEO output background & & $0.084 * *$ & $0.092^{* *}$ \\
Adjusted R & & $5.037 * *$ & $4.483 *$ \\
F-change & $0.064 * *$ & 384 & 383 \\
df & $5.496^{* *}$ & & \\
\hline
\end{tabular}

Standardized coefficients are shown with the associated $t$ statistic in parentheses.

$* p<0.05, * * p<0.01$ (two-tailed).

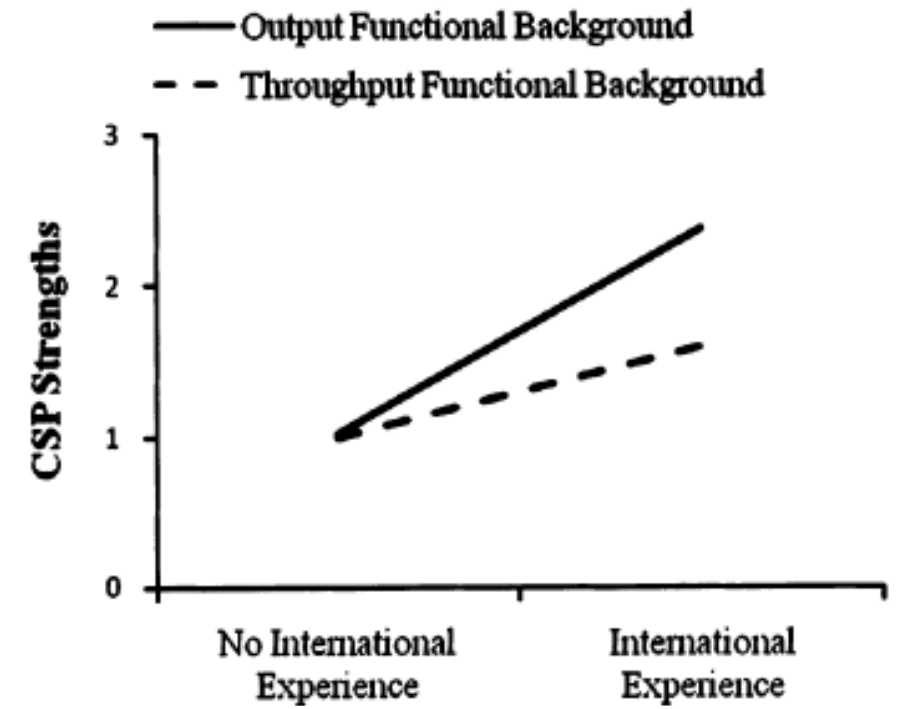

Figure 1. CEO international assignment experience, functional background, and CSP strengths.

values), and provide unique resources. These outcomes, in tum, influence the CEO's strategic decision making resulting in increased corporate social performance. Our results lend support to this argument and suggest that CEO international assignment experience is indeed positively related to higher CSP strengths and total CSP.

We further proposed that CEOs with output oriented functional backgrounds are more likely to be

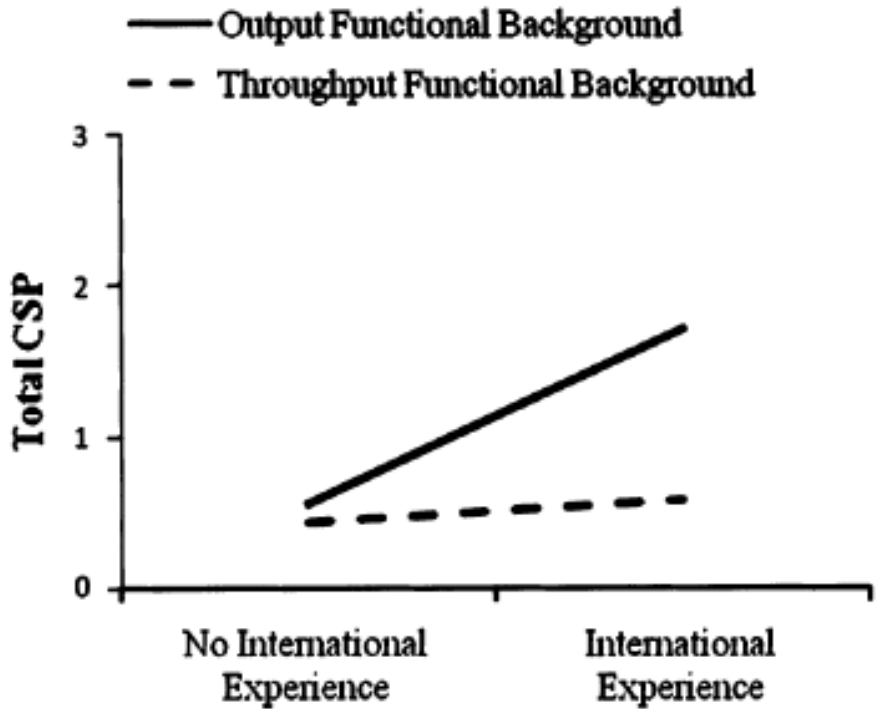

Figure 2. CEO international assignment experience, functional background, and total CSP.

affected by the outcomes of international experience related to CSP. Again, our results support this hypothesis. The effects of CEO international assignment experience on CSP strengths and total CSP are significantly enhanced by CEOs with output functional backgrounds (e.g., marketing, sales, product research, and development) compared to counterparts with throughput oriented experience (e.g., production, finance, and accounting). Importantly, our 


\section{Daniel ]. Slater and Heather R. Dixon-Fowler}

results also indicate that even when using a composite CSP score (i.e., subtracting weaknesses from strengths), international experience, and the interaction with functional background remained significant, suggesting a fairly robust predictor of CSP.

The lack of any significant results for our hypothesized relationships with CSP weaknesses may reflect what previous research has already noted. McGuire et al. (2003) suggested that the variables that encourage strong CSP may differ from those that discourage weak CSP. That is, perhaps CEO international experience is able to influence positive proactive CSP initiatives, but has no effect on the risky or avoidance approaches to CSP. An alternative perspective is offered by Maignan and Ralston (2002) who suggest that CSP represents a firm's attempts to maximize their positive impacts and minimize their negative impacts on stakeholders. Thus, our significant positive results for CEO international assignment experience and CSP strengths and lack of results for weaknesses may indicate that CEO international experience is able to help a firm maximize their positive impacts, but unable to help minimize the negative impacts on stakeholders. If so, these results may also point to an even broader implication. Perhaps the CEO's influence is limited to what we conceptualize as CSP strengths. If this is the case, future research could examine where the power lies in influencing CSP weaknesses (e.g., top management team, board of directors, etc.).

\section{Implications}

Our study has implications for both management research and practice. In contributing to management theory, our results highlight the importance of including CEO characteristics in models predicting CSP. Our examination of two such characteristics, international assignment experience and functional background, is a positive step toward answering the call for research on specific managerial variables relevant to CSP (Thomas and Simerly, 1994; Wood, 1991). In the future, CSP researchers may seek to explore additional CEO and executive characteristics related to CSP. In addition, we add to the growing body of literature examining executive international assignment experience and provide an additional outcome variable at both the firm and societal levels.

The results of this research also carry implications for management practice. Given the potential reputational and resource-based benefits of CSP (i.e., Sharma and Vredenburg, 1998; Turban and Greening, 1996; Valentine and Fleischman, 2008), along with the ever increasing pressure to manage both profits and broader social responsibilities, (Waddock and Graves, 1997), firms may recognize the importance of increasing CSP. In regards to CEO succession planning, our results suggest that firms seeking to positively influence CSP may use international assignment experience as one (of many) selection criteria. Likewise, when grooming a potential inside successor, firms may consider sending the executive on an international assignment as part of their professional development. This experience may prove especially beneficial when a future CEO has an output functional background. Interestingly, results of post hoc analysis examining the location of the CEO's international experience revealed no significant difference in terms of outcomes on CSP. In other words, it appears that it is the experience of living and working abroad itself, and not the specific location, that matters.

\section{Limitations andfuture research}

Our study is not without limitations. Drawing from theoretical and empirical work on upper echelons and international experience outcomes, we have suggested that CEO international assignment experience will influence firm CSP. However, our approach was cross-sectional in nature. Thus, the question of causal direction should be further explored. Beyond causal direction, the possibility exists that a third variable could account for the discovered relationship. For example, perhaps CEOs who are willing to accept international assignments also possess some individual trait which predisposes them toward CSP initiatives. In our own arguments we suggest that international assignment experience will influence the CEOs awareness of societal expectations, motivation toward societal action, and unique abilities. However, we were unable to directly test these implied microprocesses. If afforded access to CEOs, future researchers may be able to peer inside the black box 
regarding international assignment influences and shed additional light on our findings. In spite of this limitation, upper echelons research supports the use of demographic characteristics (i.e., unobtrusive measures) as proxies for underlying individual differences, values, and cognitive frameworks (Hambrick, 2007; Hambrick and Mason, 1984).

Future research may also address the potential for other avenues of international exposure that may influence CSP. Perhaps being born in another country or having significant exposure to another culture would have many of the same effects as international assignments. In undertaking this study, we had considered the possible influence of other cultural experiences, yet, less than $3 \%$ of the CEOs in our sample were foreign-born. 11 Although increasing in numbers, the CEOs of large firms in the U.S. are still relatively homogeneous in terms of racial background, ethnicity, and gender. As the demographic diversity of U.S. executives becomes more heterogeneous, future research may be able to explore the possible influences of demographic differences such as foreign-born executives.

This research was also limited to evaluation of the CEO. Upper echelons researchers have noted that more research considering the entire top management team is needed (Hambrick, 2007). Even be- yond the top management team, future research may also seek to evaluate the influence of international experience for the board of directors, middle management, or other organizational members.

\section{Conclusion}

The findings of this study make contributions to existing knowledge in three areas. First, consistent with upper echelons research, the results of this study further indicate the ability of executives to influence important firm outcomes. Second, this research also extends previous understanding of international experience. Previous research indicates that international assignment experience provides individual level outcomes (e.g., greater salaries; Carpenter et al., 2001) and firm level outcomes (e.g., increased firm financial performance; Daily et al., 2000). The findings presented in this research introduce a societal level outcome - enhanced CSP. Finally, as indicated at the outset of this study, understanding the antecedents to CSP has important outcomes for both firms and society at large. The findings of this study contribute to our growing understanding of CSP by indicating that a CEO who has spent time on international assignments may be more motivated and better equipped to meet the expectations of societal stakeholders.

\section{Notes}

Many of the experiences of studying abroad overlap with international assignment experience including, uprooting of an existing life, separation from the familiar, and exposure to a different culture. In addition, the outcomes of study abroad experience and international assignment experience are very similar, including long- lasting impact (Carpenter et al., 2000; Dwyer, 2004), greater awareness of international issues (Kauffinan et al., 1992; Ricks et al., 1990), and an influence on personal values (Chieffo and Griffiths, 2004; Suutari and Makela, 2007). Based on these findings, we use study abroad experience to support our arguments on the influence of international assignment experience.

2 A random sample of $5 \%$ of the biographical information from Spencer Stuart was selected for independent validation by the authors (using CEO biographies, annual reports, company websites, etc.). In all cases analyzed, the independent research confirmed the accuracy of the biographical information reported from Spencer Stuart.

3 The data provided by Spencer Stuart included many different titles for CEO functional background (e.g., marketing, product $\mathrm{R} \& \mathrm{D}$, finance, etc.). In order to measure output and throughput functional backgrounds consistent with prior conceptualizations (Herman, 2002; Hermann and Datta, 2005; Thomas and Simerly, 1994), the authors independently categorized each executive in our sample as either an output functional background (1) or a throughput functional background (0). Inter-rater reliability was $\mathrm{IX}=0.91$. The leading cause of the few discrepancies between ratings was due to some CEOs having multiple cross-categorical functional backgrounds. In such cases, the CEO was categorized based on their most recent functional experience.

4 KLD Community strength indicators include charitable giving, support for local housing and education, and volunteer programs. Community weakness indicators include negative economic impact and tax disputes. Diversity strengths indicators include hiring and promotion of women, minorities, and the disabled. Diversity weakness indicators include a lack of minority 
representation among the board of directors and management and affirmative actions fines and penalties. Employee relations strength indicators include union relations, no-layoff policies, profit sharing, and retirement benefit strength. Employee relations weakness indicators include health and safety concerns and work- force reductions. Environmental strength indicators include pollution prevention, recycling, and clean energy. Environmental weakness indicators include hazardous waste, fines and penalties for environmental regulation violations, and emissions. Product strength indicators include quality and innovation. Product weakness indicators include product safety and fines or penalties for false advertising.

5 A score of 0 signifies that a firm had no indicators of strength or weakness within the category. A score of 1 signifies that a firm had 1 indicator of strength or weakness within the category. A score of 2 signifies that a firm had 2 or more indicators of strength or weakness within the category.

${ }^{6}$ Mahoney and Thorn (2006) use the CSID database for Canadian firms as their measure for CSP. However, their scoring of strengths and weakness for each dimension (0-2) is consistent with that used in this study.

7 Industry averages were calculated using all firms rated by KLD in 2004 (3034 firms).

${ }^{8}$ Small means for CSP measures are the result of the method used to control for industry. Industry averages were subtracted from each firm score resulting in an industry adjusted value.

9 The interaction term was created using mean centered CEO international experience and CEO output functional background.

${ }^{10}$ As prior research suggests, CSP strengths and weaknesses may not be orthogonal (Mahoney and Thorn, 2006; McGuire et al., 2003; Strike et al., 2006). Note the significant positive correlation $(0.27 ; p<0.01)$ between CSP strengths and weaknesses reported in Table I. The nature of the association between the strengths and weaknesses is also evidenced by the reduced adjusted $\mathrm{R}^{2} \mathrm{~s}$ for the total CSP measure (0.064-0.092) compared to those of CSP strengths $(0.266-0.296)$ and weaknesses (0.300-0.303). Further indications of the association between strengths and weaknesses can be seen by examining the significant positive correlations between firm size and CSP strengths $(0.42 ; p<0.01)$ and CSP weak- nesses $(0.50 ; p<0.01)$. In addition, firm size is a significant positive predictor for both CSP strengths and weaknesses in all models in Tables II and III $(p<$ $0.01)$. This finding could be interpreted that large firms are more scrutinized by CSP raters and thus receive more positive and negative ratings. Taken together, this data would support the notion that firms may exhibit CSP strengths and weaknesses simultaneously and by aggregating strengths and weaknesses (subtracting weaknesses from strengths) variance is reduced.

11 We removed these 11 CEOs from our sample and reran our hierarchical regression analysis on all three forms of the dependent variable. The results were unchanged in each case.

\section{Acknowledgment}

We are grateful to Scot Burton for his helpful comments and suggestions.

\section{References}

Agle, B. R., R. K. Mitchell and J. A. Sonnenfeld: 1999, 'Who Matters to CEOs? An Investigation of Stakeholder Attributes and Salience, Corporate Performance and CEO Values', Academy of Management Journal 42(5), 507-525. doi:10.23071256973.

Athanassiou, N. and D. Nigh: 2000, 'Internationalization, Tacit Knowledge and the Top Management Teams of MNCs', Journal of International Business Studies 31(3), 471-487. doi:10.1057/palgrave.jibs.8490917.

Berman, S. L., A. C. Wicks, S. Koth and T. M. Jones: 1999, 'Does Stakeholder Orientation Matter? The Relationship Between Stakeholder Management Models and Firm Financial Performance', Academy of Management Journal 42(5), 488-506. doi:10.2307/ 256972.

Beyer, J. M., P. Chattopadhyay, E. George, W. H. Glick and D. Pugliese: 1997, 'The Selective Perception of Managers Revisited', Academy of Management Journal 40(3), 716-737. doi:10.23071257060.

Black, H. T. and D. L. Duhon: 2006, 'Assessing the Impact of Business Study Abroad Programs on Cultural Awareness and Personal Development',Journa1 of Educationfor Business 81(3), 140-144.

Brown, T. J. and P. A. Dacin: 1997, 'The Company and the Product: Corporate Associations and Consumers Product Responses', Journal of Marketing 61(1), 68-84. doi:10.230711252190.

Carlson, J. S. and K. F. Widaman: 1988, 'The Effects of Study Abroad During College on Attitudes Toward Other Cultures', International Journal of Intercultural Relations 12, 1-18. doi:10.1016/0147-1767(88)90003-X.

Carpenter, M. A. and J. W. Fredrickson: 2001, 'Top Management Teams, Global Strategic Posture, and the Moderating Role of Uncertainty', Academ y of Management Journal 44(3), 533-545. doi:10.230713069368. 
Carpenter, M. A., M. A. Geletkanycz and W. G. Sanders: 2004, 'Upper Echelons Research Revisited: Antecedents, Elements, and Consequences of Top Management Team Composition', Journal of Management 30(6), 749-778. doi:10.1016/j.jm.2004.06.001.

Carpenter, M. A., T. G. Pollock and M. M. Leary: 2003, 'Testing a Model of Reasoned Risk-Taking: Governance, the Experience of Principals and Agents, and Global Strategy in High-Technology IPO Firms', Strategic Management Journal 24(9), 803820. doi:10.1002/smj.338.

Carpenter, M. A., W. G. Sanders and H. B. Gregersen: 2000, 'International Assignment Experience at the Top can Make a Bottom-Line Difference', Human Resource Management 39(2), 277-285. doi:10.1002/ 1099-050X(200022/23)39:2/3 < 277::AID-HRM 15 $>3.0 . \mathrm{C} 0 ; 2-0$.

Carpenter, M. A., W. G. Sanders and H. B. Gregersen: 2001, 'Bundling Human Capital with Organizational Context: The Impact of International Assignment Experience on Multinational Firm Performance and CEO Pay', Academy of Management Journal 44(3), 493511. doi:10.2307/3069366.

Chieffo, L. and L. Griffiths: 2004, 'Large-Scale Assessment of Student Attitudes After a Short-Term Study Abroad Program', Frontiers: The International Journal of Study Abroad 10, 165-177.

Coombs, ]. E. and M. K. Gilley: 2005, 'Stakeholder Management as a Predictor of CEO Compensation: Main Effects and Interactions with Financial Performance', Strategic Management Journal 26, 827-840. doi:10.1002/smj.476.

Daily, C. M., S. T. Certo and D. R. Dalton: 2000, 'International Experience in the Executive Suite: The Path to Prosperity?', Strategic Management Journal 21(4), 515-523. doi:10.1002/(SICI)1097-0266(200004)21:4 <515::AID-SMJ92>3.0.C0;2-1.

Dwyer, M. M.: 2004, 'Charting the Impact of Studying Abroad', International Educator 13(1), 14-20.

Edstrom, A. and J. Galbraith: 1977, 'Transfer of Managers as a Coordination and Control Strategy in Multinational Organizations', Administrative Science Quarterly 22, 248-263. doi:10.2307/2391959.

Finkelstein, S. and D. C. Hambrick: 1996, Strategic Leadership: Top Executives and Their Effects on Organizations (West Publishing, Minneapolis).

Graves, S. B. and S. A. Waddock: 1994, 'Institutional Owners and Corporate Social Performance', Academy of Management Journal 37(4), 1034-1046. doi:10.2307I 256611.

Gregersen, H. B., A. ]. Morrison and ]. S. Black: 1998, 'Developing Leaders for the Global Frontier', Sloan Management Review 40(1), 21-32.
Gunz, H. P. and R. M. Jalland: 1996, 'Managerial Careers and Business Strategies', Academy of Management Review 21(3), 718-757. doi:10.2307/259000.

Gupta, A. K. and V. Govindarajan: 1984, 'Business Unit Strategy, Managerial Characteristics, and Business Unit Effectiveness at Strategy Implementation', Academy of ManagementJournal 27(1), 25-42. doi:10.2307/255955.

Hambrick, D. C.: 2007, 'Upper Echelons Theory: An Update', Academy of Management Review 32(2), 334343.

Hambrick, D. C. and P. A. Mason: 1984, 'Upper Echelons: The Organization as a Reflection of Its Top Managers', Academy of Management Review 9(2), 193 206. doi:10.2307/258434.

Handelman, ]. M. and S. ]. Arnold: 1999, 'The Role of Marketing Actions with a Social Dimension: Appeals to the Institutional Environment', Journal of Marketing 63, 33-48. doi:10.2307/1251774.

Hemingway, C. A. and P. W. Madagan: 2004, 'Managers' Personal Values as Drivers of Corporate Social Responsibility', Journal of Business Ethics 5, 33-44. doi: 10.1023/B:BUSI.0000020964.80208.c9.

Herman, P.: 2002, 'The Influence of CEO Characteristics on the International Diversification of Manufacturing Firms: An Empirical Study in the United States', International Journal of Management 19(2), 279-289.

Hermann, P. and D. K. Datta: 2005, 'Relationships Between Top Management Team Characteristics and International Diversification: An Empirical Investigation', British Journal of Management 16, 69-78. doi:10.1111/j.1467-8551.2005.00429.x.

Hillman, A. J. and G. D. Keim: 2001, 'Shareholder Value, Stakeholder Management, and Social Issues: What's the Bottom Line?', Strategic Management Journal 22(2), 125139. doi:10.1002/1097-0266(200101)22:2 <125::AID$\mathrm{SMJ} 150>3.0 . \mathrm{C} 0 ; 2-\mathrm{H}$.

Hosmer, L. T.: 1982, 'The Importance of Strategic Leadership', TheJournal of Business Strategy 3(2), 47-58. doi: 10.1108/eb038966.

Husted, B. W.: 2005, 'Risk Management, Real Options, and Corporate Social Responsibility', Journal of Business Ethics 60(2), 175-183. doi:10.1007/s10551-0053777-1.

Jackson, S.: 1992, 'Consequences of Group Composition for the Interpersonal Dynamics of Strategic Issue Processing', in P. Shrivastava, A. Huff and ]. Dutton (eds.), Advances in Strategic Management (JAi Press, Greenwich, CT), pp. 345-382.

Johnson, R. A. and D. W. Greening: 1999, 'The Effects of Corporate Governance and Institutional Ownership Types on Corporate Social Performance', Academy of Management Journal 42(5), 564-576. doi:10.2307I 256977. 
Kane, E. J.: 2002, 'Using Deferred Compensation to Strengthen the Ethics of Financial Regulation', Journal of Banking \& Finance 26, 1919-1933. doi:10.1016/ S0378-4266(02)00198-X.

Kauffinann, N. L., J. N. Martin and H. D. Weaver: 1992, Students Abroad: Strangers at Home (Intercultural Press, Yarmouth, ME).

Kohonen, E.: 2004, 'Leaming Through Narratives About the Impact of International Assignments on Identity', International Studies of Management \& Organization 34(3), 27-45.

Lawrence, P. and J. Lorsch: 1967, 'Differentiation and Integration in Complex Organizations', Administrative Science Quarterly 12, 1-30. doi:10.2307/2391211.

Mahoney, L. S. and L. Thom: 2006, 'An Examination of the Structure of Executive Compensation and Corporate Social Responsibility: A Canadian Investigation', Journal of Business Ethics 69(2), 149-162. doi:10.1007/s10551-006-9073-x.

Maignan, I. and D. A. Ralston: 2002, 'Corporate Social Responsibility in Europe and the U.S. Insights from Business' Self-Presentations', Journal of International Business Studies 33(3), 497-514. doi:10.1057/palgrave. jibs.8491028.

McGuire, J., S. Dow and K. Argheyd: 2003, 'CEO Incentives and Corporate Social Performance', Journal of Business Ethics 45(4), 341-359. doi:10.1023/ A:1024119604363.

McWilliams, A. and D. Siegel: 2000, 'Corporate Social Responsibility and Financial Performance: Correlation or Misspecification?', Strategic Management Journal 21, 603-609. doi:10.1002/(SICl)1097-0266(200005)21:5 < 603::AID-SMJ 101 >3.0.C0;2-3.

Mintzberg, H.: 1978, 'Patterns in Strategy Formation', Management Science 24(9), 934-949. doi:10.1287/rnnsc. 24.9.934.

Ricks, D., B. Toyne and Z. Martinez: 1990, 'Recent Developments in International Management Research', Journal ef Management 16(2), 219-253. doi:10.1177/ 014920639001600202.

Rokeach, M.: 1973, The Nature Human Values (Free Press, New York).

Roth, K.: 1995, 'Managing International Interdependence: CEO Characteristics', Academy of Management Journal 38(1), 200-232. doi:10.2307/256733.

Sambharya, R. B.: 1996, 'Foreign Experience of Top Management Teams and International Diversification Strategies of U.S. Multinational Corporations', Strategic Management Journal 17, 739-746. doi:10.1002/(SICI) 1097-0266(199611)17:9 <739::AID-SMJ846 > 3.0.CO; $2-\mathrm{K}$.

Schwartz, S. H. and W. Bilski: 1987, 'Toward a Universal Psychological Structure on Human Values', Journal of
Personality and Social Psychology 53, 550-562. doi: 10.1037/0022-3514.53.3.550.

Sharfinan, M.: 1996, 'The Construct Validity of the Kinder, Lydenberg and Domini Social Performance Ratings Data', Journal of Business Ethics 15(3), 287-296. doi:10.1007 /BF00382954.

Sharma, S. and H. Vredenburg: 1998, 'Proactive Corporate Environmental Strategy and the Development of Competitively Valuable Organizational Capabilities', Strategic Management Journal 19(8), 729-754. doi:10.1002/(SICI)1097-0266(199808)1 9:8 < 729::AIDSMJ967 > 3.0.C0;2-4.

Simerly, R. L.: 2000, 'A Theoretical Examination of the Relationship Between Chief Executive Officers and Corporate Social Performance', International Journal of Management 17(2), 218-223.

Simerly, R. L.: 2003, 'An Empirical Examination of the Relationship Between Management and Corporate Social Performance', International Journal of Management 20(3), 353-359.

Song, J. H.: 1982, 'Diversification Strategies and the Experience of Top Executives of Large Firms', Strategic Management Journal 3(4), 377-381. doi:10.1002/ smj.4250030411.

Strike, V. M., J. Gao and P. Bansal: 2006, 'Being Good While Being Bad: Social Responsibility and the International Diversification of US Firms', Journal of International Business Studies 37, 850-862. doi:10.1057I palgrave.jibs.8400226.

Suutari, V. and K. Makela: 2007, 'The Career Capital of Managers with Global Careers', Journal of Managerial Psychology 22(7), 628-648. doi:10.1108/02683940710 820073.

Thomas, A. S., R. J. Litschert and K. Ramaswamy: 1991, 'The Performance Impact of Strategy Manager CoAlignment: An Empirical Examination', Strategic Management Journal 12(7), 509-523. doi:10.1002/ smj.4250120704.

Thomas, A. S. and R. L. Simerly: 1994, 'The Chief Executive Officer and Corporate Social Performance: An Interdisciplinary Examination', Journal ef Business Ethics 13(12), 959-968. doi:10.1007/BF00881665.

Thomlison, T. D.: 1991, 'Effects of a Study-Abroad Program on University Students: Toward a Predictive Theory of Intercultural Contact', Paper Presented at the Annual Intercultural and Communication Conference, 22 February 1991, Miami, FL.

Turban, D. B. and D. W. Greening: 1996, 'Corporate Social Performance and Organizational Attractiveness to Prospective Employees', Academy of Management Journal 40(3), 658-672. doi:10.2307/257057.

Valentine, S. and G. Fleischman: 2008, 'Ethics Programs, Perceived Corporate Social Responsibility and Job 
Satisfaction', Journal of Business Ethics 77, 159-172. doi:10.1007 /s10551-006-9306-z.

Waddock, S. A. and S. B. Graves: 1997, 'The Corporate Social Performance-Financial Performance Link', Strategic Management Journal 18(4), 303-319. doi:10.1002/ (SICI)1097-0266(199704)18:4 < 303::AID-SMJ869 > 3.0.C0;2-G.

Waldman, D. A., D. S. Siegel and M. Javidan: 2006, 'Components of CEO Transformation Leadership and Corporate Social Responsibility', Journal of Management Studies 43(8), 1703-1725. doi:10.1111/j.1467-6486. 2006.00642.x.

Wallace, D. H.: 1999, 'Academic Study Abroad: The Long-term Impact on Alumni Careers, Volunteer Activities, World and Personal Perspectives', Dissertation, The Claremont Graduate University, DAI-A, 60102, Aug 1999, 365 pp.

Walsh, J. P.: 1988, 'Selectivity and Selective Perception: An Investigation of Managers' Belief Structures and
Information Processing', Academy of Management Journal 37, 873-896. doi:10.23071256343.

Wood, D. J.: 1991, 'Corporate Social Performance Revisited', Academy Of Management Review 16(4), 691718. doi:10.23071258977.

Zorn, C. R.: 1996, 'The Long-Term Impact on Nursing Students of Participating in International Education', Journal of Professional Nursing 12(2), 106-110. doi:10.1016/S8755-7223(96)80056-1. 